\title{
The police state
}

On the surface, beehives and ant nests seem to be model societies, with each individual striving for the common good. But maintaining this social order sometimes calls for brutal tactics. John Whitfield reports.

urder, torture and imprisonment - these are the standard tools of repressive regimes. But if you imagine that human societies have a monopoly on such tactics, think again. Social insects perfected the police state long before people got in on the act.

The workers in bee, ant and wasp colonies forgo their own reproduction to raise the brood of their queen. Such is a worker honeybee's devotion to the collective, she will eviscerate herself by stinging any animal rash enough to attack the hive - a selflessness that has long fascinated naturalists.

We now know that workers receive their evolutionary payoff through their relatedness to the monarch. As the queen's daughters, they share many genes with her other offspring. By caring for the regal brood, they ensure their own genetic inheritance.

But in any society, it is possible to prosper by breaking the rules. Worker honeybees do occasionally lay their own eggs. As well as being against the queen's interests, this puts them at odds with the rest of the workforce. And in the late 1980s, evolutionary ecologist Francis Ratnieks, now at the University of Sheffield, UK, showed that honeybee workers act as a 'police force' that cracks down on miscreants, eating their eggs ${ }^{1}$. "Worker policing is a mechanism by which a society resolves its conflicts," says Ratnieks. "I think it's the best example of conflict resolution in nature."

Policing by egg-eating is common to all species of Apis, not just the familiar domestic honeybee, A. mellifera ${ }^{2}$. And bees are not alone - the phenomenon has recently been observed in some species of wasp $\mathrm{p}^{3}$ and in a group of ants. "It may be very widespread," says Ratnieks.

But sometimes policing breaks down. Beehives occasionally dissolve into anarchy, as workers begin to reproduce en masse 5 . And a parasitic subspecies of honeybee is wreaking havoc in South Africa, destroying colonies by evading their police ${ }^{6}$. Evolutionary biologists hope that studying such faceoffs between authoritarianism and anarchy will provide a deeper understanding of the balance between cooperation and selfishness

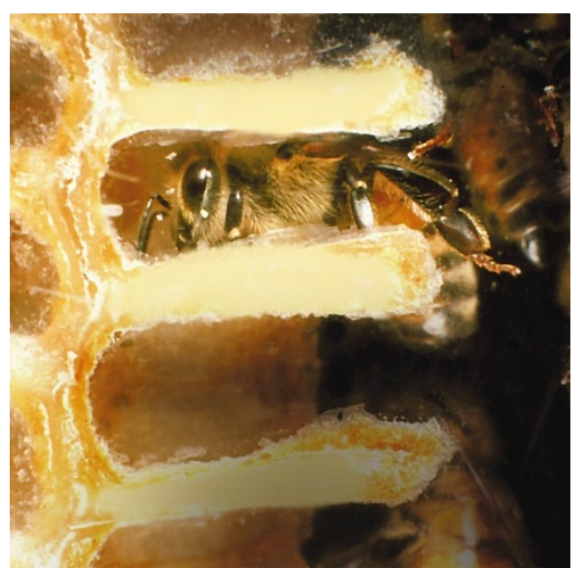

at many levels, from genes within the genome to individuals in human societies.

Sociality has evolved about a dozen times in the Hymenoptera - bees, wasps and ants. This is probably linked to their unusual method of sex determination, called haplodiploidy. In the Hymenoptera, sexual reproduction always produces female offspring, which are diploid - they have two sets of chromosomes, just like humans of both sexes. Male hymenopterans, however, develop from unfertilized eggs, and carry only one set of chromosomes. These 'haploid' males produce sperm that are genetically identical. This is different from diploid animals, which shuffle

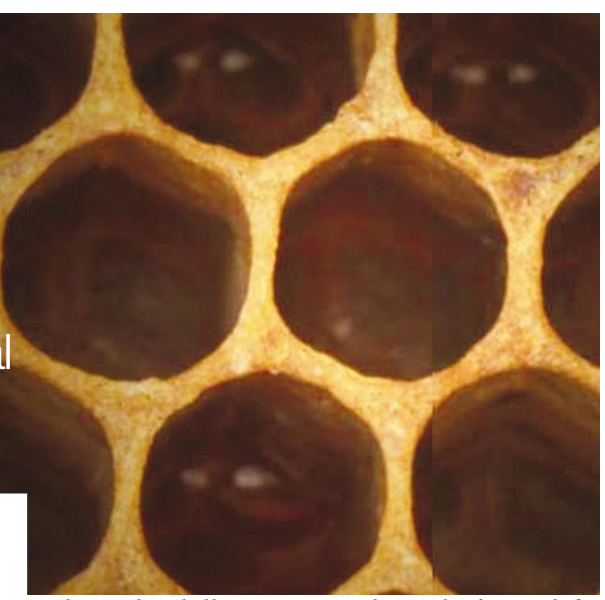

A honeybee kills an a renegade worker's egg, left.

maternal and paternal chromosomes into their haploid sperm or eggs, giving infinite genetic possibilities.

\section{Family ties}

In human families, brothers and sisters each share half of their genes by common descent - their coefficient of relatedness $(r)$, to use the technical term, is 0.5 . The same is true for parents and offspring. For half-brothers or half-sisters, $r$ is 0.25 .

But haplodiploidy creates some bizarre family dynamics (see diagram, opposite). A mother's relatedness to her son is 0.5 , but consider the same relationship from his perspective and $r$ rises to 1.0. Sister-brother relationships are also unequal: from the sister's viewpoint, $r$ is 0.25 ; from the brother's, it is 0.5. Mothers and daughters have a relatedness of 0.5 , whichever way you look at it, and $r$ for two sisters is always 0.75 .

These final two figures are key, because they mean that a female can pursue her genetic interests more effectively by raising her mother's daughters rather than her own. This helps to explain why most females in social Hymenoptera do not reproduce. If the

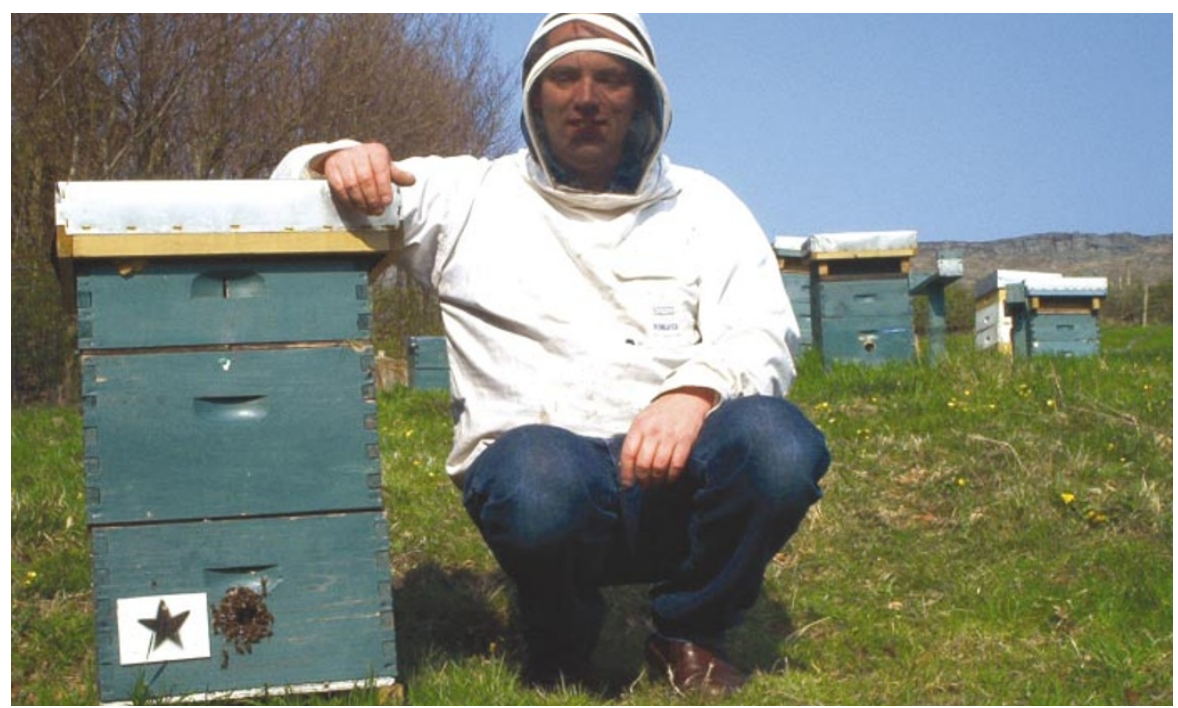

Police supervisor: Francis Ratnieks was the first to describe honeybees' disciplinary tactics. 


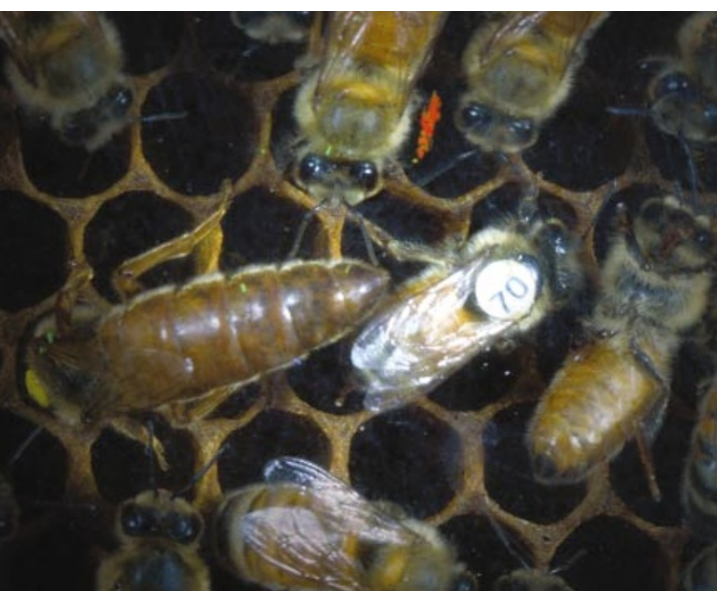

An egg-laying worker bee (marked) is ignored...

queen is mother to the entire female workforce, they have little to gain by producing their own daughters.

In many species, workers are physically incapable of mating. And in honeybees, the monarchs exploit their subjects by mating with up to 20 males; workers are thus tending to young that are mostly half, not full, sisters, with a relatedness of 0.375 rather than 0.75 .

Worker honeybees cannot rebel by mating, but they can lay unfertilized eggs that will develop into sons, with a relatedness of 0.5. But $r$ once again explains why other workers destroy sneakily laid eggs. To most of the workforce, another worker's son is a halfnephew, with a relatedness of just 0.125 , so the majority gain if workers' eggs are culled and everyone concentrates on raising the queen's brood. The result, as Ratnieks has found, is a police force so pervasive that it rivals the former East Germany's infamous Stasi.

\section{God save the queen}

At the top of the security apparatus sits the queen, producing pheromones that instruct the workers to carry on with the usual business of repression. Most loyally shut down their ovaries and keep watch for any subversives. In this way, the success of worker policing is conspicuous by the rarity of transgressors. Only about 3 of the 30,000 or so worker honeybees in a typical hive have functioning ovaries, showing the inequality of the struggle between a lone selfish worker and the rest of her caste. Although these rogue females can lay about $7 \%$ of a colony's male eggs, effective policing means that only 1 in 1,000 males has a worker for a mother?

Indeed, workers' eggs usually get eaten within hours of being laid ${ }^{1}$, betrayed by their lack of a chemical badge unique to the queen's eggs ${ }^{8}$. Honeybee workers also seem to detect when their colleagues are about to break the rules, becoming aggressive to workers with active ovaries?. But as with human dictatorships, the death of the leader can trigger major societal changes. When the queen dies, and her pheromones no longer pervade the hive, the workers

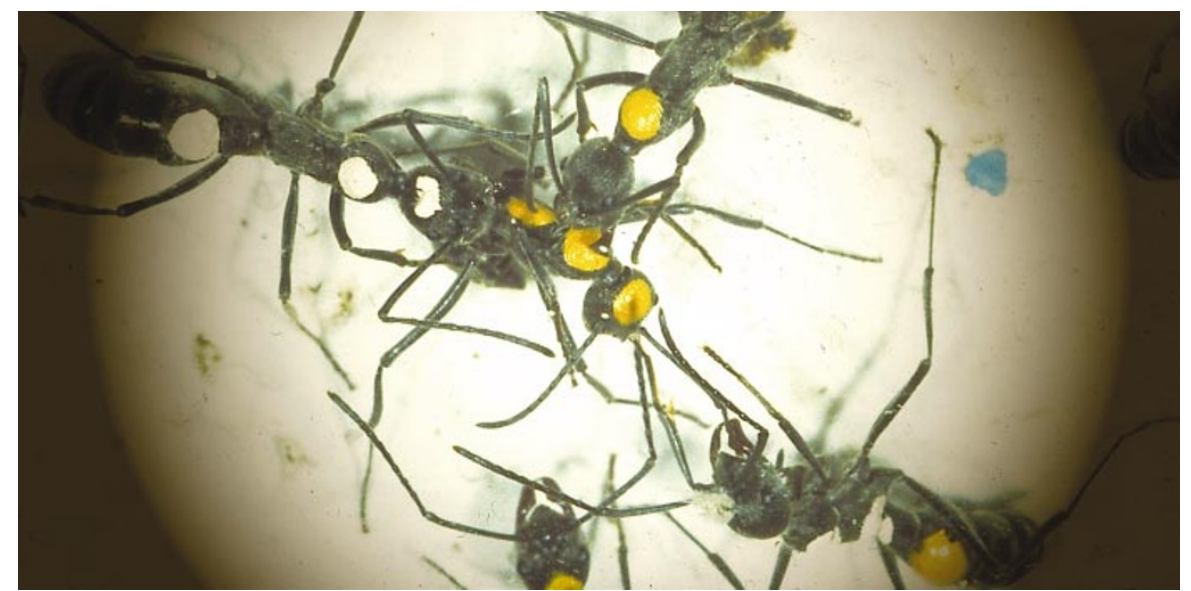

...but this ponerine ant is assaulted by fellow workers as a punishment for attempting to reproduce. hurl themselves into a frenzy of egg-laying ${ }^{10}$.

Honeybees are the most advanced insect police state so far discovered. Wasp societies are smaller and simpler, but give another elegant example of animal behaviour matching evolutionary theory. Again, it all comes down to $r$. In some species of vespine wasp, the queen mates with just one male, whereas in others she mates repeatedly. Where queens are monogamous, and all workers are therefore full sisters, the relatedness between a worker and a fellow worker's son rises to 0.375 , compared with 0.125 for species in which the queen mates several times. In both cases, workers are related to the queen's sons by an $r$ of 0.25 .

So workers should tolerate one another's egg-laying if their queen mates just once because 0.375 is greater than 0.25 - but clamp down on renegade egg-layers if the queen is more promiscuous. Sure enough, this is what Ratnieks and his Sheffield colleague Kevin Foster found when they compared different wasp species ${ }^{3}$. They even saw policing varying within species: in the saxon wasp (Dolichovespula saxonica), queens may mate once or several times. Policing only occurs in colonies with promiscuous queens ${ }^{11}$.

\section{The fascist regime}

In some ponerine ants, both social structure and policing are much less sophisticated. Living in colonies of 100 or fewer individuals in tropical forests, these ants have no rigid divide between queen and workers. Instead, all females have the potential to reproduce sexually. But only one or a few do, because small colonies cannot support many breeders.

Breeding females are called gamergates, and head a pecking order that has older workers at the bottom and younger workers - wannabe gamergates - in the middle. This hierarchy is enforced by both egg-eating and more brutal policing methods. If a young worker attempts to reproduce, she is spreadeagled by her fellows and kept immobilized for hours or even days. At the end of her sentence, the best she can hope for is a reduction in rank and loss of reproductive capability. Often she is mutilated or killed ${ }^{4}$.

But ponerine gamergates do not enforce the same iron control over their security appa-

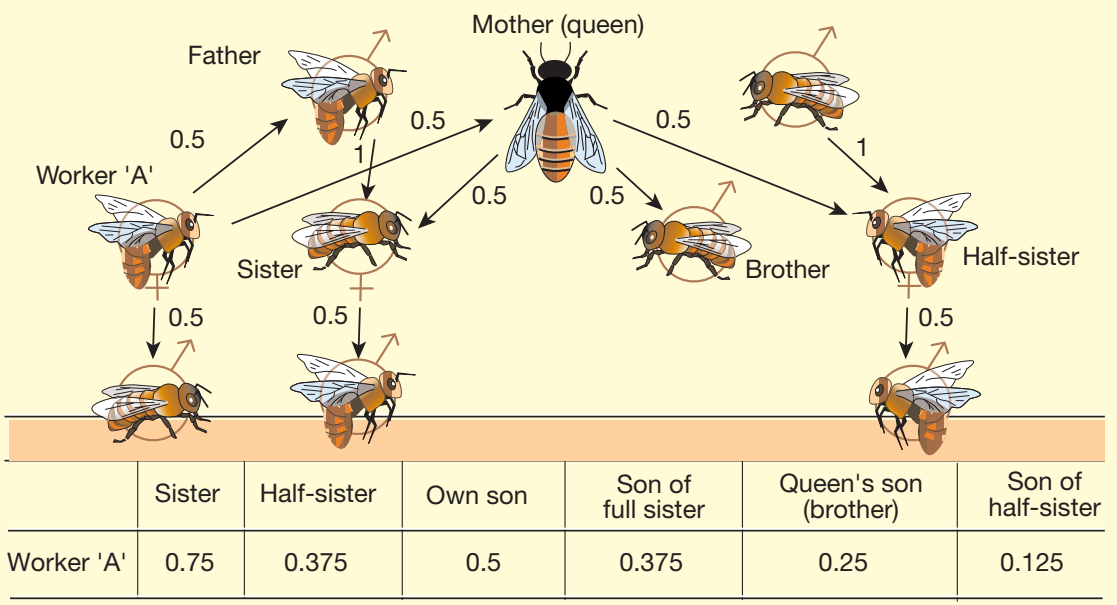

Numbers game: to determine the degree of relatedness between a worker and her nest-mates, follow the arrows, multiplying the values on each route and adding the products. 
